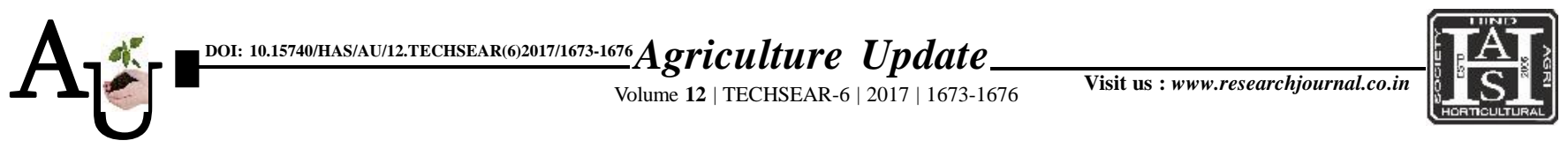

\title{
Research Article: Studies on growth parameters and nutrient uptake of sweet corn in relation to different crop geomtery and nutrient management under Chhattisgarh plain ecosystem
}

\section{NIRJHARNEE NANDEHA, Y.K. DEWANGAN AND PREM LAL SAHU}

Article Chronicle: Received :

17.07.2017;

Accepted :

01.08 .2017

KeY WORDS:

Growth parameters, Nutrient uptake, Sweet corn, Relation Different crop geomtery

Author for correspondence :

\section{NIRJHARNEE}

\section{NANDEHA}

Department of

Agronomy, Indira

Gandhi Krishi

Vishvavidyalaya, RAIPUR

(C.G) INDIA

Email: nirjharnee

nandeha04@gmail.com
SUMMARY : The results revealed that all the growth parameters and yield attributes viz., higher plant height $(119.12 \mathrm{~cm})$, dry matter accumulation $\left(58.25 \mathrm{~g} \mathrm{plant}^{-1}\right)$, SPAD value $(43.67)$, cob length $(17.26 \mathrm{~cm})$, cob girth $(16.76 \mathrm{~cm})$, green cob weight $\left(255.46 \mathrm{~g} \mathrm{cob}^{-1}\right)$ and number of grains $\mathrm{cob}^{-1}\left(397.72 \mathrm{cob}^{-1}\right)$ were improved in wider crop geometry of $60 \mathrm{~cm} \times 30 \mathrm{~cm}\left(\mathrm{G}_{3}\right)$. However, narrow plant spacing $(45 \mathrm{~cm} \times 20 \mathrm{~cm})$ proved superior in terms of number of cobs ha ${ }^{-1}\left(62016\right.$ cobs ha $\left.^{-1}\right)$, green stover $\left(186.37 \mathrm{q} \mathrm{ha}^{-1}\right)$, green cob yield $\left(98.03 \mathrm{q} \mathrm{ha}^{-1}\right)$ and harvest index $(33.68 \%)$.

How to cite this article : Nandeha, Nirjharnee, Dewangan,Y.K. and Sahu, Prem Lal (2017). Studies on growth parameters and nutrient uptake of sweet corn in relation to different crop geomtery and nutrient management under Chhattisgarh plain ecosystem. Agric. Update, 12(TECHSEAR-6) : 1673-1676; DOI: 10.15740/HAS/AU/ 12. TECHSEAR(6)2017/1673-1676. 